\title{
The Need to Establish An Affective Domain Assessment Strategy for Your Program
}

\author{
Willard D. Bostwick \\ Indiana University Purdue University Indianapolis
}

\begin{abstract}
Several proposed ABET engineering technology criteria have roots in the affective as well as cognitive domain. If these outcomes are assessed wholly as mental activities, measures will be sought which determine the student's ability to recall, comprehend, apply, synthesize, and evaluate appropriate skills. It is possible to do all of these things without demonstrating that a graduate will either incorporate or accept this knowledge or application of principles as a guide to everyday professional practice or personal conduct.
\end{abstract}

An assessment practice based upon affective domain criteria would examine the student's state of mind resulting from one or more directed learning experiences as a result of the technology curriculum. Using the same proposed outcomes, measures are needed to detect how successfully the student receives, values, organizes and integrates curricular content into his or her own life style. Unless one can determine if the student's ability to successfully perform these outcomes when appropriate has been integrated into practice or conduct and it is evidenced in day-to-day behavior, the result has not been effectively measured.

This paper introduces the differences between cognitive assessment taxonomy and affective assessment taxonomy, distinctions between an assessment system and an assessment strategy, and identifies various approaches that can be employed to incorporate affective domain assessment into the overall engineering technology assessment plan. Unless this is done, a partial and less than comprehensive assessment program will result.

\section{Introduction}

Perhaps an appropriate place to start is at the end rather than at the beginning. This is because most believe they can recognize where assessment started, e.g., ABET, but unless they are clairvoyant few understand the conclusion. ABET has defined the end game to be evidence that assessment results are applied for program improvement and development. ${ }^{1}$ How this is accomplished should be the result of deliberate strategy, not the incidental result of an assessment program or system.

Engineering Criteria 2000, the new engineering program evaluative criteria, spawned a dramatic increase in the scholarship of assessment. There have been a large number of conference papers about engineering assessment. Discussions specific to engineering technology assessment are less common. Most assessment presentations, however, in either engineering or engineering technology focus on who did (or is going to do) it, methodological issues or conduct of surveys, and particular issues about what can be measured and why. Few actually broach the issue of an assessment strategy. 
A War should not commence without a plan for termination. ${ }^{2}$ Neither should assessment. Does the end for assessment lie in a strategy or a system? Can one exist independently of the other? If, a decision not to have a formal plan or system for assessment is made, then no plan is a deliberate strategic decision but offers little hope for directed program improvement. This paper takes the converse position that an assessment strategy should result from a formal plan or system.

Selection of a framework for assessment is the basic step. An assessment system identifies many outcomes that may be measured and a variety of potential methods available for these purposes. Rarely will it be feasible or prudent, however, to employ each method for every outcome. Without consideration of the end result, there is considerable risk that assessment initiatives become fragmented and unorganized. Assessment strategy is a determination of which methods will be used to collect data about each outcome and how frequently it will be done.

\section{Determination of Assessment Strategy}

On the balance, is more assessment better? Should every measurable outcome be measured by all alternative methods? The engineering technology assessment plan should allow a framework that enables an institution to determine the following: what questions are to be asked; how often and exactly how; where are the questions going to be asked; and who will be asked or studied? Even casual inference suggests it would be impractical to evaluate or assess everything that moves. While many academic program outputs are measurable, not everything is important. Maximum program improvement and/or development results when a strategy to focus on assessment in significant areas of interest is pursued.

Each institution first must determine an appropriate list of academic program outcomes for its own environment. Primacy should be afforded the educational objectives defined by own institutional goals and operating culture. Engineering technology programs in the future are expected to either augment these outcomes in accord with criteria proposed by the Technology Accreditation Commission or in the absence of campus expectations establish individual program outcomes compatible with ABET-TAC Criteria. ${ }^{3}$ These common program outcomes then define a framework for establishing measurable outcomes for each course in the academic syllabus.

The proposed TAC Criterion \#1 statements are comparable in many respects to a similar list adopted for engineering. Unlike the statements adopted for engineering, which include both criteria and outcomes, however, statements furnished for engineering technology first must be translated into an accessible outcome for each engineering technology program. An example of one way to do this is given in Table 1.

Several things are immediately observable. Many original criteria are actually compound statements. These must first be sub-divided into more than one measurable outcome. Some easily can be broken into four or five. These outcomes very likely should also be further differentiated into a more basic list of learning outcomes on a course-by-course level for assessment. The first criterion, i.e., "demonstrate an appropriate mastery..." appears quite 


\begin{tabular}{|c|c|c|}
\hline \multicolumn{3}{|c|}{$\begin{array}{l}\text { TABLE 1. PROPOSED CRITERIA FOR ACCREDITING ENGINEERING TECHNOLOGY } \\
\text { PROGRAMS AND POTENTIAL MEASURABLE OUTCOME STATEMENTS }\end{array}$} \\
\hline \multicolumn{3}{|c|}{ AN ENGINEERING TECHNOLOGY PROGRAM IS EXPECTED TO PREPARE GRADUATES WHO: } \\
\hline \# & $\begin{array}{c}\text { COLUMN A } \\
\text { ORIGINAL CRITERION STATEMENT }\end{array}$ & $\begin{array}{c}\text { COLUMN B } \\
\text { CORRESPONDING OUTCOME STATEMENT }\end{array}$ \\
\hline A & $\begin{array}{l}\text { DEMONSTRATE AN APPROPRIATE MASTERY OF THE } \\
\text { KNOWLEDGE, TECHNIQUES, SKILLS AND MODERN TOOLS OF } \\
\text { THEIR DISCIPLINE }\end{array}$ & {$\left[\begin{array}{l}{[\text { IF “B” THROUGH “G” ARE ACCOMPLISHED, }]} \\
\text { THEN “A”IS REDUNDANT. }\end{array}\right]$} \\
\hline B & $\begin{array}{l}\text { APPLY CURRENT KNOWLEDGE AND ADAPT TO EMERGING } \\
\text { APPLICATIONS IN MATHEMATICS, SCIENCE, ENGINEERING AND } \\
\text { TECHNOLOGY }\end{array}$ & $\begin{array}{l}\text { DEMONSTRATE AN ABILITY TO APPLY CURRENT KNOWLEDGE, } \\
\text { TECHNIQUES, SKILLS AND MODERN TOOLS OF THEIR } \\
\text { DISCIPLINE AND } \\
\text { DEMONSTRATE AN ABILITY TO ADAPT TO EMERGING } \\
\text { APPLICATIONS OF KNOWLEDGE, TECHNIQUES, SKILLS AND } \\
\text { MODERN TOOLS OF THEIR DISCIPLINE }\end{array}$ \\
\hline $\mathrm{C}$ & $\begin{array}{l}\text { CONDUCT, ANALYZE AND INTERPRET EXPERIMENTS AND } \\
\text { APPLY EXPERIMENTAL RESULTS TO IMPROVE PROCESSES }\end{array}$ & $\begin{array}{l}\text { DEMONSTRATE AN ABILITY TO CONDUCT, ANALYZE AND } \\
\text { INTERPRET EXPERIMENTS AND } \\
\text { DEMONSTRATE AN ABILITY TO APPLY EXPERIMENTAL RESULTS } \\
\text { TO IMPROVE PROCESSES }\end{array}$ \\
\hline $\mathrm{D}$ & $\begin{array}{l}\text { APPLY CREATIVITY IN THE DESIGN OF SYSTEMS, COMPONENTS } \\
\text { OR PROCESSES APPROPRIATE TO PROGRAM OBJECTIVES }\end{array}$ & $\begin{array}{l}\text { DEMONSTRATE AN ABILITY TO APPLY CREATIVITY IN THE } \\
\text { DESIGN OF SYSTEMS, COMPONENTS OR PROCESSES } \\
\text { APPROPRIATE TO PROGRAM OBJECTIVES } \\
\end{array}$ \\
\hline $\mathrm{E}$ & FUNCTION EFFECTIVELY ON TEAMS & $\begin{array}{l}\text { DEMONSTRATE AN ABILITY TO FUNCTION EFFECTIVELY ON } \\
\text { TEAMS }\end{array}$ \\
\hline $\mathrm{F}$ & IDENTIFY, ANALYZE AND SOLVE TECHNICAL PROBLEMS & $\begin{array}{l}\text { DEMONSTRATE AN ABILITY TO IDENTIFY, ANALYZE AND SOLVE } \\
\text { TECHNICAL PROBLEMS }\end{array}$ \\
\hline G & COMMUNICATE EFFECTIVELY & DEMONSTRATE AN ABILITY TO COMMUNICATE EFFECTIVELY \\
\hline $\mathrm{H}$ & $\begin{array}{l}\text { RECOGNIZE THE NEED FOR AND POSSESS THE ABILITY TO } \\
\text { PURSUE LIFELONG LEARNING }\end{array}$ & $\begin{array}{l}\text { DEMONSTRATE AN ABILITY TO RECOGNIZE THE NEED FOR } \\
\text { LIFELONG LEARNING AND } \\
\text { DEMONSTRATE AN ABILITY TO PURSUE LIFELONG LEARNING }\end{array}$ \\
\hline I & $\begin{array}{l}\text { UNDERSTAND PROFESSIONAL, ETHICAL AND SOCIAL } \\
\text { RESPONSIBILITIES }\end{array}$ & $\begin{array}{l}\text { DEMONSTRATE AN ABILITY TO UNDERSTAND PROFESSIONAL, } \\
\text { ETHICAL AND SOCIAL RESPONSIBILITIES }\end{array}$ \\
\hline $\mathrm{J}$ & $\begin{array}{l}\text { RECOGNIZE CONTEMPORARY PROFESSIONAL, SOCIETAL AND } \\
\text { GLOBAL ISSUES AND BE AWARE OF AND RESPECT DIVERSITY }\end{array}$ & $\begin{array}{l}\text { DEMONSTRATE AN ABILITY TO RECOGNIZE CONTEMPORARY } \\
\text { PROFESSIONAL, SOCIETAL AND GLOBAL ISSUES AND } \\
\text { DEMONSTRATE AN ABILITY TO RECOGNIZE AND RESPECT } \\
\text { DIVERSITY }\end{array}$ \\
\hline $\mathrm{K}$ & $\begin{array}{l}\text { HAVE DEVELOPED A COMMITMENT TO QUALITY, TIMELINESS } \\
\text { AND CONTINUOUS IMPROVEMENT }\end{array}$ & $\begin{array}{l}\text { DISPLAY A COMMITMENT TO QUALITY, TIMELINESS AND } \\
\text { CONTINUOUS IMPROVEMENT }\end{array}$ \\
\hline
\end{tabular}

redundant with criteria "b" through "g". It seems reasonable to argue that if an engineering technology program can be demonstrated to successfully satisfy criteria " $b$ " to "g" then it has fulfilled "a" as well. Similar logic suggests that if the program satisfies "b" to "g" then graduates have also demonstrated "an ability to pursue lifelong learning." Each of the first seven criteria and part of the eighth are readily identifiable as objectives that emphasize mental activities, e.g., knowing or learning specific facts, ideas, and techniques that can be employed for an intellectual task. These are considered cognitive objectives and easily lend themselves to straightforward assessment. ${ }^{4}$ Even complex abilities associated with these criteria often can be learned in a onesemester or one-year course, and assessment frequently is accomplished by an examination administered at the end of the course among other methods.

The four remaining criteria however, i.e., highlighted by boldface action verbs in Table 1-Column B, are not amenable to cognitive assessment methodology. These are characteristics or traits that usually develop relatively slowly and are often not readily visible for assessment except over much longer intervals of time, perhaps even years. ${ }^{5}$ Introducing change in these areas require educational objectives that will influence how students receive, 
respond, value, organize, and characterize knowledge. These are affective domain traits or objectives. Though appreciably more difficult to consciously design into the curriculum and to devise methods for direct assessment, engineering technology faculty will recognize these as situations where students do make distinctions between problem solving and attitudes, between thinking and feeling, and between acting and thinking or feeling.

A simple comparison of the taxonomic structure for both the affective domain and cognitive domain is given at Table 2. ${ }^{6}$ Most engineering technology faculty are already familiar

\begin{tabular}{|c|c|}
\hline \multicolumn{2}{|c|}{ TABLE 2. SIMPLIFIED COMPARISON OF AFFECTIVE AMD COGNITIVE DOMAINS } \\
\hline \multicolumn{2}{|c|}{ COGNITIVE TAXONOMY } \\
\hline$\underline{\text { LEVEL OF LEARNING }}$ & ASSOCIATED MENTAL ACTIVITIES \\
\hline KNOWLEDGE & Recall and recognition \\
\hline COMPREHENSION & Understanding; translation, interpretation, extrapolation \\
\hline$\underset{\downarrow}{\text { APPLICATION }}$ & Use of learned material in specific instances \\
\hline ANALYSIS & Understanding of organizational structure; interrelationships \\
\hline SYNTHESIS & Creation of new structures/relationships \\
\hline$\underset{\Downarrow}{\text { EVALUATION }}$ & Value judgments \\
\hline \multicolumn{2}{|c|}{ AFFECTIVE TAXONOMY } \\
\hline$\underline{\text { LEVEL OF LEARNING }}$ & $\underline{\text { STATE OF MIND }}$ \\
\hline RECEIVING & Being aware; attending willingly or selectively \\
\hline RESPONDING & Complying; acting willingly \\
\hline VALUING & Accepting a value for it's perceived worth; appreciation \\
\hline$\underset{\downarrow}{\text { ORGANIZING }}$ & Comparing, relating, synthesizing values into one's own system \\
\hline$\underset{\Downarrow}{\text { CHARACTERIZING }}$ & Integrating values into life style \\
\hline
\end{tabular}

with the concept of an educational taxonomy and employ, either consciously or subconsciously, a hierarchical taxonomy similar to one of these for identification and determination of course outcomes and construction of exam questions. Examples of typical instructional objectives and of useful behavioral terms for specification of learning outcomes from the affective or cognitive domains if needed are offered, respectively, in Appendix A and B.

Was it a deliberate act then when ABET specified the final four outcomes in Table 1 as affective terms or an unintended result? Whether deliberate or not a presumption that engineering technology graduates must be able to achieve and/or successfully perform these 
activities at more than a mere a mental level is valid.

Those responsible for the engineering technology assessment program must always remember that assessment looks at the consequence of outcomes in a complex environment. This includes but is not limited to classroom instructional effort, the total engineering technology curriculum, the instructional academic environment and the campus culture. Caution is recommended when interpreting data ... it may not always represent what is initially so obvious.

Another important part of assessment strategy is to determine how often and exactly how data will be collected. Often it is possible to use different methodologies to look at the same or very similar dimensions of the same outcome. For another project, the author identified 25 different generic ways to collect program assessment data. There are probably others. Each method has characteristic strengths and weaknesses. Some are clearly inappropriate or ineffective to measure some outcomes but not all. However, no single measurement technique by itself is adequate for program assessment.

The assessment plan will furnish valuable information about which outcomes need to be assessed and identify the menu of acceptable methods for assessment. The plan will also enable identification of those outcomes where potential to collect the same information multiple times is present and indicate assessment 'blind spots' where outcomes are not adequately sampled. A good assessment plan will also allow for controlled multiple assessments of the same trait using alternate means to ensure both reliability and validity. Assessment strategy, however, must be used to determine priorities or when outcomes from the plan are to be assessed, what specific methods are to be used at that time, and anticipated uses to be made of the information obtained. The assessment plan should include provisions for systematic feedback and incorporation into the program improvement cycle. How this information may also be used or shared beyond the academic level is an administrative question but should be defined from the beginning. ${ }^{7}$

\section{Final Four Assessment}

Intercollegiate athletics is a big-time activity on many engineering technology program campuses. Feedback recently submitted to ASEE Prism suggests "it is important for the stability of and continuation of society that all members, including engineers, have an understanding and appreciation for all aspects of living . . . ." The final four statements proposed in Criterion \#1 appear an effort to do just that, i.e., make the link between an engineering technologists education and the graduates ability to make contributions for the stability of and for the continuation of society. Achieving the final four in engineering technology education is more important than reaching the final four in athletics. How do we prove that we are doing it?

Quantitative assessment of the final four, with the exception previously noted about presumption of an ability to pursue lifelong learning, via objective data is improbable. There will be opportunities to collect qualitative data, to collect very subjective data, and an occasional isolated piece of hard data determined as much by chance as by design. Typical data sources include attitude measurement instruments, opinionnaires and surveys, and focus groups augmented by one-on-one conversations, chance encounters, personal correspondence and "clipping files" as sometimes maintained by alumni or other institutional offices. These sources 
offer evidence that may corroborate some graduates reach the final four. Generally, however, evidence encountered in this manner will be positive but very, very incomprehensive.

Academic program design, however, can be used to increase the probability that graduates will be prepared to reach the final four. Syllabi by design may incorporate whenever opportune planned learning objectives that enable students to prepare for this challenge. These will include activities that would enhance interest in life-long learning, activities that include problems with social and ethical scenarios, activities that require a horizontal as well as vertical integration of knowledge, activities that introduce the student to undifferentiated contextual solutions, and a sufficient number of these activities across the curriculum that doing what is "right" or "ethical" or "civil" becomes characteristic. 9,10,11 This appears to be what the Technology Accreditation Commission expects for an accreditable engineering technology program under the proposed criteria.

\section{Summary}

Engineering technology programs are about to embark on a new accreditation era. Meeting the expectations for assessment will require that each institution devise a conceptually sound assessment plan and a dynamic assessment strategy to ensure its success.

The Technology Accreditation Commission has proposed eleven criterion statements to guide this effort. Seven preliminary statements address specific cognitive content areas that are essential to equip engineering technology graduates with the knowledge and skills necessary for performance. The last four criterion statements identify key areas where institutions are expected to enable students to recognize and adapt their behaviors for the collective good of mankind. Doing the latter necessitates that faculty members become knowledge about affective domain outcomes and the importance these areas also hold for design of learning outcomes for each course in the syllabus.

Enabling every engineering technology graduate to reach the "final four" is academic. Assessment is a continuous and a deliberate process to increase the probably of that outcome. 


\begin{tabular}{|c|c|c|c|}
\hline \multicolumn{4}{|c|}{$\begin{array}{c}\text { APPENDIX A. } \\
\text { AFFECTIVE DOMAIN CATEGORIES AND CHARACTERISTICS }\end{array}$} \\
\hline CATEGORY & CHARACTERISTICS & $\begin{array}{c}\text { TYPICAL } \\
\text { INSTRUCTIONAL } \\
\text { OBJECTIVES }\end{array}$ & $\begin{array}{c}\text { USEFUL BEHAVIORAL } \\
\text { TERMS FOR } \\
\text { SPECIFYING LEARNING } \\
\text { OUTCOMES }\end{array}$ \\
\hline RECEIVING & $\begin{array}{l}\text { Phenomena or stimuli } \\
\text { associated with getting, } \\
\text { holding, and directing the } \\
\text { students' attention }\end{array}$ & $\begin{array}{l}\text { - Listens attentively } \\
\text { - Shows awareness of } \\
\text { the importance of } \\
\text { learning } \\
\text { - Shows sensitivity to } \\
\text { human needs and social } \\
\text { problems } \\
\text { - Accepts differences of } \\
\text { race and culture } \\
\text { - Attends closely to } \\
\text { classroom activities }\end{array}$ & $\begin{array}{l}\text { Asks, chooses, describes, } \\
\text { follows, gives, holds, identifies, } \\
\text { locates, names, points to, } \\
\text { selects, sits erect, replies, uses }\end{array}$ \\
\hline RESPONDING & $\begin{array}{l}\text { Refers to active participation } \\
\text { on the part of the student. } \\
\text { Expects that student not only } \\
\text { attends to the phenomenon but } \\
\text { also reacts to it in some way. }\end{array}$ & $\begin{array}{l}\text { - Completes assigned } \\
\text { homework } \\
\text { - Obeys school rules } \\
\text { - Participates in class } \\
\text { discussion } \\
\text { - Completes laboratory } \\
\text { work } \\
\text { - Volunteers for special } \\
\text { tasks } \\
\text { - Shows interest in } \\
\text { subject } \\
\text { - Enjoys helping others } \\
\end{array}$ & $\begin{array}{l}\text { Answers, assists, complies, } \\
\text { conforms, discusses, greets, } \\
\text { helps, labels, performs, } \\
\text { practices, presents, reads, } \\
\text { recites, reports, selects, tells, } \\
\text { writes }\end{array}$ \\
\hline VALUING & $\begin{array}{l}\text { Concerned with the value or } \\
\text { worth a student attaches to a } \\
\text { particular object, phenomenon, } \\
\text { or behavior. }\end{array}$ & $\begin{array}{l}\text { - Demonstrates belief in the } \\
\text { democratic process } \\
\text { - Appreciates the role of } \\
\text { science in every life } \\
\text { - Shows concern for welfare } \\
\text { of others } \\
\text { - Demonstrates problem- } \\
\text { solving attitude } \\
\text { - Demonstrates commitment } \\
\text { to social improvement }\end{array}$ & $\begin{array}{l}\text { Completes, describes, } \\
\text { differentiates, explains, follows, } \\
\text { forms, initiates, invites, joins, } \\
\text { justifies, proposes, reads, } \\
\text { reports, selects, shares, studies, } \\
\text { works }\end{array}$ \\
\hline ORGANIZING & $\begin{array}{l}\text { Concerned with bringing } \\
\text { together different values, } \\
\text { resolving conflicts between } \\
\text { them, and beginning of an } \\
\text { internally consistent value } \\
\text { system. }\end{array}$ & $\begin{array}{l}\text { - Recognizes need for } \\
\text { balance between freedom } \\
\text { and responsibility } \\
\text { - Recognizes role of } \\
\text { systematic planning in } \\
\text { solving problems } \\
\text { - Accepts responsibility for } \\
\text { own behavior } \\
\text { - Understands and accepts } \\
\text { own strengths and } \\
\text { limitations } \\
\text { - Formulates a life plan in } \\
\text { harmony with abilities, } \\
\text { interests, and beliefs }\end{array}$ & $\begin{array}{l}\text { Adheres, alters, arranges, } \\
\text { combines, compares, completes, } \\
\text { defends, explains, generalizes, } \\
\text { identifies, integrates, modifies, } \\
\text { orders, organizes, prepares, } \\
\text { relates, synthesizes }\end{array}$ \\
\hline CHARACTERIZING & $\begin{array}{l}\text { At this level the individual has } \\
\text { a value system that has } \\
\text { controlled behavior for a } \\
\text { sufficiently long enough period } \\
\text { to develop a "characteristic" } \\
\text { life style. }\end{array}$ & $\begin{array}{l}\text { - Displays safety } \\
\text { consciousness } \\
\text { - Demonstrates self-reliance } \\
\text { in working independently } \\
\text { - Practices cooperation in } \\
\text { group activities } \\
\text { - Uses objective approach in } \\
\text { problem solving } \\
\text { - Demonstrates industry, } \\
\text { punctuality and self- } \\
\text { discipline } \\
\text { - Maintains good health } \\
\text { habits } \\
\end{array}$ & $\begin{array}{l}\text { Acts, discriminates, displays, } \\
\text { influences, listens, modifies, } \\
\text { performs, practices, proposes, } \\
\text { qualifies, questions, revises, } \\
\text { serves, solves, uses, verifies }\end{array}$ \\
\hline
\end{tabular}




\begin{tabular}{|c|c|c|c|}
\hline \multicolumn{4}{|c|}{$\begin{array}{c}\text { APPENDIX B. } \\
\text { Cognitive DoMAIN CATEGORIES AND CHARACTERISTICS } \\
\end{array}$} \\
\hline CATEGORY & CHARACTERISTICS & $\begin{array}{c}\text { TYPICAL } \\
\text { INSTRUCTIONAL } \\
\text { OBJECTIVES }\end{array}$ & $\begin{array}{c}\text { USEFUL BEHAVIORAL } \\
\text { TERMS FOR } \\
\text { SPECIFYING LEARNING } \\
\text { OUTCOMES }\end{array}$ \\
\hline KNOWLEDGE & $\begin{array}{l}\text { Remembering previously } \\
\text { learned material or bringing to } \\
\text { mind appropriate information. }\end{array}$ & $\begin{array}{l}\text { - Knows common terms } \\
\text { - Knows specific facts } \\
\text { - Knows methods and } \\
\text { procedures } \\
\text { - Knows basic concepts } \\
\text { - Knows principles }\end{array}$ & $\begin{array}{l}\text { Defines, describes, identifies, } \\
\text { labels, lists, matches, names, } \\
\text { outlines, reproduces, selects, } \\
\text { states }\end{array}$ \\
\hline COMPREHENSION & $\begin{array}{l}\text { Ability to grasp meaning, } \\
\text { translate, or interpret material } \\
\text { or estimate future trends }\end{array}$ & $\begin{array}{l}\text { - Understands facts and } \\
\text { principles } \\
\text { - Interprets verbal material } \\
\text { - Interprets charts and } \\
\text { graphs } \\
\text { - Translates verbal material } \\
\text { to mathematical formulas } \\
\text { - Estimates future } \\
\text { consequences implied in } \\
\text { data } \\
\text { - Justifies methods and } \\
\text { procedures }\end{array}$ & $\begin{array}{l}\text { Converts, defends, } \\
\text { distinguishes, estimates, } \\
\text { explains, extends, generalizes, } \\
\text { gives examples, infers, } \\
\text { paraphrases, predicts, rewrites, } \\
\text { summarizes }\end{array}$ \\
\hline APPLICATION & $\begin{array}{l}\text { Ability to apply learned } \\
\text { material in new and concrete } \\
\text { situations. Requires higher } \\
\text { level of understanding than } \\
\text { those of comprehension. }\end{array}$ & $\begin{array}{l}\text { - Applies concepts and } \\
\text { principles to new situations } \\
\text { - Applies laws and theories } \\
\text { to practical situations } \\
\text { - Solves mathematics } \\
\text { problems } \\
\text { - Constructs charts and } \\
\text { graphs } \\
\text { - Demonstrates correct } \\
\text { usage of a method or } \\
\text { procedure }\end{array}$ & $\begin{array}{l}\text { Changes, computes, } \\
\text { demonstrates, discovers, } \\
\text { manipulates, modifies, } \\
\text { operates, predicts, prepares, } \\
\text { produces, relates, shows, solves, } \\
\text { uses }\end{array}$ \\
\hline ANALYSIS & $\begin{array}{l}\text { Ability to break down material } \\
\text { into its component parts so that } \\
\text { its organizational structure is } \\
\text { understood. }\end{array}$ & $\begin{array}{l}\text { - Recognizes unstated } \\
\text { assumptions } \\
\text { - Recognizes logical fallacies } \\
\text { in reasoning } \\
\text { - Distinguishes between } \\
\text { facts and inferences } \\
\text { - Evaluates the relevancy of } \\
\text { data } \\
\text { - Analyzes the organizational } \\
\text { structure of work }\end{array}$ & $\begin{array}{l}\text { Breaks down, diagrams, } \\
\text { differentiates, discriminates, } \\
\text { distinguishes, identifies, } \\
\text { illustrates, infers, outlines, } \\
\text { points out, relates, selects, } \\
\text { separates, subdivides }\end{array}$ \\
\hline SYNTHESIS & $\begin{array}{l}\text { Ability to put parts together to } \\
\text { form a new whole. }\end{array}$ & $\begin{array}{l}\text { - Writes a well organized } \\
\text { theme } \\
\text { - Gives a well organized } \\
\text { speech } \\
\text { - Proposes a plan for an } \\
\text { experiment } \\
\text { - Integrates learning from } \\
\text { different areas into a plan } \\
\text { for problem solving } \\
\text { - Formulates a new scheme } \\
\text { for classifying objects }\end{array}$ & $\begin{array}{l}\text { Categorizes, combines, } \\
\text { compiles, composes, creates, } \\
\text { devises, designs, explains, } \\
\text { generates, modifies, organizes, } \\
\text { plans, rearranges, reconstructs, } \\
\text { relates, reorganizes, revises, } \\
\text { rewrites, summarizes, tells, } \\
\text { writes }\end{array}$ \\
\hline EVALUATION & $\begin{array}{l}\text { Ability to judge value of } \\
\text { material or a given purpose } \\
\text { based on definite criteria. } \\
\text { Student may be given the } \\
\text { criteria or expected to } \\
\text { determine them. }\end{array}$ & $\begin{array}{l}\text { - Judges logical consistency } \\
\text { of written material } \\
\text { - Judges adequacy by which } \\
\text { conclusions are supported } \\
\text { by facts } \\
\text { - Judges value of a work by } \\
\text { use of internal criteria } \\
\text { - Judges value of a work by } \\
\text { use of external standards }\end{array}$ & $\begin{array}{l}\text { Appraises, compares, } \\
\text { concludes, contrasts, criticizes, } \\
\text { describes, discriminates, } \\
\text { explains, justifies, interprets, } \\
\text { relates, summarizes, supports }\end{array}$ \\
\hline
\end{tabular}


Bibliography

1. Accreditation Board for Engineering and Technology. Engineering Criteria 2000. (http://www.abet.md.us/EAC/eac2000.html)

2. Clausewitz, C. On War. Princeton, NJ: Princeton University Press, 1976, trans. and ed. By Michael Howard and Peter Paret, p. 87.

3. Accreditation Board for Engineering and Technology. Proposed New TAC Criteria. (http://www.abet.org/tac/New_TAC_Criteria.htm)

4. Bloom, B.S. (ed). Taxonomy of Educational Objectives, Handbook I: Cognitive Domain. New York: David McKay Company, Inc., 1956.

5. Krathwohl, D.R., Bloom, B.S., and Masia, B.B. Taxonomy of Educational Objectives: The Classification of Educational Goals, Handbook II: Affective Domain. New York: David McKay Company, Inc., 1964.

6. Bostwick, W.D. "Assessing in the Affective Domain," Proceedings Sixth International Conference on Engineering and Technology Education, Cincinnati, OH, June 2000.

7. Doepker, P.E. "The Development and Implementation of an Assessment Plan for Engineering Programs: A Model for Continuous Assessment," Proceedings 1999 ASEE Annual Conference, Charlotte, NC, June 1999.

8. Reed, F.E. “Too Much Distance,” ASEE Prism, December 1999, p. 7.

9. Bengiamin, N.N., "Development and Implementation of an ABET ED2000 Assessment Program: Pros and Cons," Proceedings 1999 ASEE Annual Conference, Charlotte, NC, June 1999.

10. McGourty, J., Besterfield-Sacre, M., and Shuman, L., “ABET's Eleven Student Learning Outcomes (a-k): Have We Considered the Implications?" Proceedings 1999 ASEE Annual Conference, Charlotte, NC, June 1999.

11. Krathwohl et al, ibid.

12. Ibid.

13. Bloom, ibid.

\section{WILLARD D. BOSTWICK}

Dr. Bostwick is Director, Engineering Education Excellence Center $\left(\mathrm{E}^{3} \mathrm{C}\right)$ and Professor of Organizational Leadership and Supervision at the Purdue School of Engineering and Technology at IUPUI. A member of the School's outcomes assessment committee, his areas of emphasis are on behavior and strategy within organizations, economic development, data analysis and collection, and program articulation. He received B.S. and Ph.D. degrees, respectively, in mathematics from Northern Illinois University and in education/management science from the University of Kentucky. He is also a graduate of the management Development Program at the Harvard University Graduate School of Education. 